\title{
Peningkatan kreativitas anak melalui media cetak buah-buahan di TK Pertiwi Pasar Baru Bayang
}

\author{
Marna Syafrida \\ TK Pertiwi Pasar Baru Bayang
}

\begin{abstract}
Abstrak
Fenomena yang ada selama ini kreativitas yang dimiliki oleh anak pada umumnya masih rendah.Keadaan tersebut di sebabkan karena kurangnya pengembangan kreativitas sejak usia dini. Anak Usia Dini pada khususnya di TK Pertiwi Pasar Baru Bayang Kabupaten Pesisir Selatan juga masih memiliki daya kreativitas yang rendah. Hal ini dapat di lihat dari kegiatan anak sehari-hari dimana masih menunggu guru, tidak mempunyai ide sendiri, belum bisa mengungkapkan idenya sendiri kalau tidak dibantu oleh guru, anak-anak masih tergantung dengan guru. Fokus penelitian ini adalah mengenai Peningkatan Kreativitas Anak melalui Media Cetak Buah-buahan di TK Pertiwi Pasar Baru Bayang Kabupaten Pesisir Selatan melalui tiga aspek yaitu anak dapat menggambar sesuai idenya,membentuk benda (kertas) sesuai imajinasinya, mencampur warna sesuai kreativitasnya. Berdasarkan ketiga aspek yang telah diteliti dan melihat persentase dari masing-masing aspek terjadinya peningkatan yang signifikan. Maka dapat diambil kesimpulan bahwa melalui media cetak buah-buahan dapat meningkatakn kreativitas anak di TK Pertiwi Pasar Baru Bayang Kabupaten Pesisir Selatan.
\end{abstract}

Keywords: Kreativitas, media cetak reproduction in any medium, provided the original work is properly cited. (C2018 by author

\section{PENDAHULUAN}

Pendidikan Anak Usia Dini adalah suatu proses pembinaan tumbuh kembang anak usia lahir hingga enam tahun secara menyeluruh yang mencakup aspek fisik dan nonfisik dengan memberikan rangsangan bagi perkembangan jasmani, rohani (moral dan spiritual), motorik, akal pikiran, emosional dan sosial yang tepat agar anak tumbuh dan berkembang secara optimal. Undang-undang RI No. 20 Tahun 2003 tentang sistem pendidikan nasional bab 1 ayat 14, menyatakan Pendidikan Anak Usia Dini adalah upaya pembinaan yang ditujukan kepada anak sejak lahir sampai dengan usia enam tahun yang dilakukan melalui pemberian rangsangan pendidikan untuk membantu pertumbuhan dan perkembangan jasmani dan rohani agar anak memiliki kesiapan memasuki pendidikan lebih lanjut. 
Anak Usia Dini adalah individu yang sedang mengalami proses pertumbuhan dan perkembangan yang pesat bahkan dikatakan sebagai lompatan perkembangan karena itu usia dini dikatakan sebagai golden age (usia emas) yaitu usia yang berharga dibanding usia selanjutnya. Usia tersebut merupakan fase kehidupan yang unik dengan karakteristik khas, baik secara fisik, psikis, sosial dan moral. Anak pada usia dini memiliki kemampuan belajar luar biasa khususnya pada masa awal kanak-kanak. Keinginan anak untuk belajar menjadikan anak aktif dan eksploratif. Anak belajar dengan seluruh panca inderanya untuk memahami sesuatu dan dalam waktu singkat anak beralih ke hal lain untuk dipelajari. Lingkunganlah yang terkadang menjadi penghambat dalam mengembangkan kemampuan belajar anak dan sering kali lingkungan mematikan keinginan anak untuk bereksplorasi.

Masa kanak-kanak merupakan masa paling penting karena merupakan pembentukan pondasi kepribadian yang menentukan pengalaman anak selanjutnya. Karakteristik Anak Usia Dini menjadi mutlak dipahami untuk memiliki generasi yang mampu mengembangkan diri secara optimal mengingat penting usia tersebut. Mengembangkan kreativitas anak memerlukan peran penting pendidik hal ini secara umum sudah banyak dipahami. Anak kreatif memuaskan rasa keingintahuannya melalui berbagai cara seperti berekplorasi, bereksperimen dan banyak mengajukan pertanyaan pada orang lain. Suratno (2005) menjelaskan anak kreatif dan cerdastidak terbentuk dengan sendirinya melainkan perlu pengarahan salah satunya dengan memberi kegiatan yang dapat mengembangkan kreativitas anak.

Fenomena yang ada selama ini kreativitas yang dimiliki oleh anak pada umumnya masih rendah. Hal ini dapat diketahui dengan masih banyaknya anak-anak yang belum mampu menghasilkan karyanya sendiri, mereka masih meniru karya milik orang lain. Keadaan tersebut di sebabkan karena kurangnya pengembangan kreativitas sejak usia dini. AnakUsia Dini pada khususnya di TK Pertiwi Pasar Baru Bayang Kabupaten Pesisir Selatan juga masih memiliki daya kreativitas yang rendah. Hal ini dapat di lihat dari kegiatan anak sehari-hari dimana masih menunggu guru, tidak mempunyai ide sendiri, belum bisamengungkapkan idenya sendiri kalau tidak dibantu oleh guru, anak-anak masih tergantung dengan guru.Media yang digunakan guru untuk mengembangkan kreativitas anak masih kurang.

Permasalahan tersebut di atas disebabkan oleh beberapa faktor diantaranya media pembelajaran yang kurang menarik, pembelajaran yang hanya menitik beratkan pada membaca dan berhitung saja dan penggunaan metode yang statis sehingga membuat anak bosan dan kurang dapat memunculkan ide kreatifnya. Selain itu penggunaan metode bercerita kurang optimal di terapkan di TK Pertiwi Pasar Baru Bayang Kabupaten Pesisir Selatan . Kegiatan yang bisa dilakukan untuk mengembangkan kreativitas anak antara lain dengan musik, mengunjungi pameran, menonton pertunjukan wayang, olahraga, bercerita dan lain-lain.

Mengatasi masalah di atas, maka diperlukan upaya perbaikan dalam proses pembelajaran yang dapat mengembangkan kemampuan kreativitas anak dalam suasana pembelajaran yang menarik dan menyenangkan bagi anak. Seperti halnya dengan kegiatan meletakkan atau memegang sesuatu objek dengan menggunakan media cetak.Berdasarkan latar belakang tersebut, maka penulis melakukan penelitian tentang "Peningkatan Kreativitas Anak melalui Media Cetak Buah-buahan diTK Pertiwi Pasar Baru Bayang Kabupaten Pesisir Selatan.

\section{METODE}

Penelitian ini berbentuk penelitian tindakan kelas (Classroom Action Research) dengan menggunakan pendekatan kualitatif. Hal ini sesuai dengan pendapat Arikunto (2008:3) bahwa: "Penelitian tindakan kelas adalah merupakan suatu pencermatan terhadap kegiatan belajar berupa sebuah tindakan yang sengaja dimunculkan dan terjadi dalam sebuah kelas secara bersama”.

Subjek dalam penelitian ini adalah anak-anak TK Pertiwi Pasar Baru Bayang Kabupaten Pesisir Selatan tahun pelajaran 2017/2018 khususnya pada anak kelompok B1 yang berjumlah 16orang anak murid, terdiri dari 6 anak laki-laki dan 10 anak perempuan.

Prosedur pelaksanaan penelitian ini akan dilakukan secara bersiklus yang dimulai dengan siklus pertama, jika siklus pertama tidak berhasil maka dapat dilakukan dengan siklus kedua. Siklus kedua ini ditentukan dari hasil siklus pertama yang terdiri dari kegiatan perencanaan tindakan, pelaksanaan tindakan, observasi dan refleksi. Rancangan siklus pada penelitian ini memakai rancangan dari Sanjaya (2010) komponennya adalah adanya perencanaan (Planning), adanya tindakan itu sendiri (Action), Observasi (Observation), Refleksi (Reflection), yakni kegiatan yang dilakukan untuk mengkaji dan mengarah sesuai dengan hasil observasi, terutama untuk melihat berbagai kelemahan yang perlu diperbaiki. 
Instrumen dalam penelitian ini adalah observasi untuk mengecek kegiatan yang dilakukan berdasarkan indikator yang ditentukan sebelumnya, fortofolio yang berisikan tentang penilaian pembelajaran yang telah dilaksanakan selama proses pembelajaran berlangsung yang berupa hasil unjuk kerja anak yang diamati secara langsung maupun dari hasil dokumentasi berupa foto.

Indikator keberhasilan dalam penelitianmedia cetak buah-buahan untuk meningkatkan kreativitas Anak Usia Dini di TK Pertiwi Pasar Baru Bayang Kabupaten Pesisir Selatan, menurut Arikunto (2006) ditandai dengan beberapa hal seperti : 1) 75\% media cetak buah-buahandapat dipahami anak TK Pertiwi Pasar Baru Bayang Kabupaten Pesisir Selatan; 2) 75\% anak TK Pertiwi Pasar Baru Bayang Kabupaten Pesisir Selatan mampu melakukan mencetak dengan media cetak buah-buahan.

\section{HASIL PENELITIAN DAN PEMBAHASAN}

\section{Deskripsi Kondisi Awal}

Sebelum peneliti melakukan penelitian di TK Pertiwi Pasar Baru Bayang Kabupaten Pesisir Selatan ditemukan bahwa peningkatan kreativitas anak kelas B1 di TK Pertiwi Pasar Baru Bayang Kabupaten Pesisir Selatan masih rendah. Hal ini terlihat sebagian besar anak di kelas mengalami kesulitan ketika mengembangkan kreativitasnya, lebih jelas lihat tabel dibawah ini :

Tabel 1. Hasil Observasi KreativitasAnak (Sebelum Tindakan) Pada Kondisi Awal

\begin{tabular}{|c|c|c|c|c|c|c|c|}
\hline \multirow[t]{3}{*}{ No } & \multirow[t]{3}{*}{ Aspek yang dinilai } & \multicolumn{6}{|c|}{ Nilai } \\
\hline & & \multicolumn{2}{|c|}{ ST } & \multicolumn{2}{|c|}{$\mathbf{T}$} & \multicolumn{2}{|c|}{$\mathrm{R}$} \\
\hline & & $\mathbf{F}$ & $\%$ & $\mathbf{F}$ & $\%$ & $\mathbf{F}$ & $\%$ \\
\hline 1 & $\begin{array}{l}\text { Anak dapat menggambar sesuai } \\
\text { idenya }\end{array}$ & 3 & 18,75 & 3 & 18,75 & 10 & 62,5 \\
\hline 2 & $\begin{array}{l}\text { Anak dapat membentuk benda } \\
\text { sesuai imajinasinya }\end{array}$ & 2 & 12,5 & 2 & 12,5 & 12 & 75 \\
\hline 3 & $\begin{array}{l}\text { Anak dapat mencampur warna } \\
\text { sesuai dengan kreativitasnya }\end{array}$ & 2 & 12,5 & 1 & 6,25 & 13 & 81,25 \\
\hline \multicolumn{2}{|c|}{ Nilai Rata-rata } & & 14,58 & & 12,5 & & 72,92 \\
\hline
\end{tabular}

Berdasarkan tabel di atas pada kondisi awal sebelum tindakan dideskripsikan bahwa pada aspek ke-1 anak dapat menggambar sesuai idenya, yang sangat tinggi berjumlah 3 orang dengan persentase 18,75\%, anak yang tinggi berjumlah 3 orang dengan persentase 18,75\%, dan anak yang rendah berjumlah 10 orang dengan persentase $62,5 \%$. Untuk aspek ke-2 Anak dapat membentuk benda sesuai imajinasinya, yang sangat tinggi berjumlah 2 orang dengan persentase $12,5 \%$, anak yang tinggi berjumlah 2 orang dengan persentase $12,5 \%$, dan anak yang rendah berjumlah 12 orang dengan persentase $75 \%$. Untuk aspek ke-3 anak dapat mencampur warna sesuai dengan kreativitasnya, yang sangat tinggi berjumlah 2 orang dengan persentase 12,25\%, anak yang tinggi berjumlah 1 orang dengan persentase $6,25 \%$, dan anak yang rendah berjumlah 13 orang dengan persentase $81,25 \%$.

\section{Deskripsi Siklus I}

Siklus I dilaksanakan sebanyak 3 kali pertemuan. Pertemuan pertama dilaksanakan pada hari Rabu, tanggal 28 Februari 2018, pertemuan kedua pada hari Kamis, tanggal 1 Maret 2018, dan pertemuan ketiga pada hari Kamis, tanggal 8 Maret 2018.

\section{Pertemuan Pertama}

Hasil dari observasi setiap aspek yang dinilai dalam peningkatan kreativitas anak melalui media cetak buah-buahan pada siklus I pertemuan I dapat dilihat pada tabel berikut: 
Tabel 2. Hasil Observasi Peningkatan Kreativitas Anak melalui

Media Cetak Buah-buahan Pada Siklus I Pertemuan Pertama

\begin{tabular}{|c|c|c|c|c|c|c|c|}
\hline \multirow[t]{3}{*}{ No } & \multirow[t]{3}{*}{ Aspek yang dinilai } & \multicolumn{6}{|c|}{ Nilai } \\
\hline & & \multicolumn{2}{|c|}{ ST } & \multicolumn{2}{|c|}{$\mathbf{T}$} & \multicolumn{2}{|c|}{$\mathrm{R}$} \\
\hline & & $\mathbf{F}$ & $\%$ & $\mathbf{F}$ & $\%$ & $\mathbf{F}$ & $\%$ \\
\hline 1 & $\begin{array}{l}\text { Anak dapat menggambar sesuai idenya } \\
\text { melalui media cetak }\end{array}$ & 7 & 43,75 & 4 & 25 & 5 & 31,25 \\
\hline 2 & $\begin{array}{l}\text { Anak dapatmembentuk benda (kertas) sesuai } \\
\text { imajinasinya melalui media cetak }\end{array}$ & 7 & 43,75 & 3 & 18,75 & 6 & 37,5 \\
\hline 3 & $\begin{array}{l}\text { Anak dapat mencampur warna sesuai } \\
\text { kreativitasnya }\end{array}$ & 5 & 31,25 & 2 & 12,5 & 9 & 56,25 \\
\hline \multicolumn{2}{|c|}{ Nilai Rata-rata } & & 39,58 & & 18,75 & & 41,67 \\
\hline
\end{tabular}

Deskripsi hasil yang diperoleh pada pertemuan pertama ini adalah sebagai berikut: pada aspek ke-1 anak dapat menggambar sesuai idenya melalui media cetak, yang sangat tinggi berjumlah 7 orang dengan persentase $43,75 \%$, anak yang tinggi berjumlah 4 orang dengan persentase $25 \%$, dan anak yang rendah berjumlah 5 orang dengan persentase $31,25 \%$. Untuk aspek ke-2 anak dapat membentuk benda (kertas) sesuai imajinasinya melalui media cetak, yang sangat tinggi berjumlah 7 orang dengan persentase 43,75\%, anak yang tinggi berjumlah 3 orang dengan persentase $18,75 \%$, dan anak yang rendah berjumlah 6 orang dengan persentase 37,5\%. Untuk aspek ke-3 anak dapat mencampur warna sesuai kreativitasnya, yang sangat tinggi berjumlah 5 orang dengan persentase $31,25 \%$, anak yang tinggi berjumlah 2 orang dengan persentase $12,5 \%$, dan anak yang rendah berjumlah 9 orang dengan persentase $56,25 \%$.

\section{Pertemuan Kedua}

Hasil dari observasi setiap aspek peningkatan kreativitas anak melalui media cetak buah-buahan pada siklus I pertemuan keduadapat dilihat pada tabel berikut:

Tabel 3. Hasil Observasi Peningkatan Kreativitas Anak melalui Media Cetak Buah-buahan Pada Siklus I Pertemuan Kedua

\begin{tabular}{|c|c|c|c|c|c|c|c|}
\hline \multirow[t]{3}{*}{ No } & \multirow[t]{3}{*}{ Aspek yang dinilai } & \multicolumn{6}{|c|}{ Nilai } \\
\hline & & \multicolumn{2}{|c|}{ ST } & \multicolumn{2}{|c|}{$\mathbf{T}$} & \multicolumn{2}{|c|}{$\mathrm{R}$} \\
\hline & & $\mathbf{F}$ & $\%$ & $\mathbf{F}$ & $\%$ & $\mathbf{F}$ & $\%$ \\
\hline 1 & $\begin{array}{l}\text { Anak dapat menggambar sesuai } \\
\text { idenya melalui media cetak }\end{array}$ & 9 & 56,25 & 2 & 12,5 & 5 & 31,25 \\
\hline 2 & $\begin{array}{l}\text { Anak dapat membentuk benda } \\
\text { (kertas) sesuai imajinasinya melalui } \\
\text { media cetak }\end{array}$ & 8 & 50 & 3 & 18,75 & 5 & 31,25 \\
\hline 3 & $\begin{array}{l}\text { Anak dapat mencampur warna sesuai } \\
\text { kreativitasnya }\end{array}$ & 7 & 43,75 & 2 & 12,5 & 7 & 43,75 \\
\hline \multicolumn{2}{|c|}{ Nilai Rata-rata } & & 50 & & 14,58 & & 35,42 \\
\hline
\end{tabular}

Deskripsi hasil yang diperoleh pada pertemuan kedua ini adalah sebagai berikut: pada aspek ke-1 anak dapat menggambar sesuai idenya melalui media cetak, yang sangat tinggi berjumlah 9 orang dengan persentase $56,25 \%$, anak yang tinggi berjumlah 2 orang dengan persentase $12,5 \%$, dan anak yang rendah berjumlah 5 orang dengan persentase $31,25 \%$. Untuk aspek ke-2 Anak dapat membentuk benda (kertas) sesuai imajinasinya melalui media cetak, yang sangat tinggi berjumlah 8 orang dengan persentase $50 \%$, anak yang tinggi berjumlah 3 orang dengan persentase 18,75\%, dan anak yang rendah berjumlah 5 orang dengan persentase $31,25 \%$. Untuk aspek ke-3 anak dapat mencampur warna sesuai kreativitasnya, yang sangat tinggi berjumlah 7 orang dengan persentase $43,75 \%$, anak yang tinggi berjumlah 2 orang dengan persentase 12,5\%, dan anak yang rendah berjumlah 7 orang dengan persentase $43,75 \%$.

\section{Pertemuan Ketiga}

Hasil dari observasi setiap aspek yang dinilai dalam peningkatan kreativitas anak melalui media cetak buah-buahan pada siklus I pertemuan III dapat dilihat pada tabel berikut: 
Tabel 4. Hasil Observasi Peningkatan Kreativitas Anak melalui Media Cetak Buah-buahan Pada Siklus I Pertemuan Ketiga (Setelah Tindakan)

\begin{tabular}{|c|c|c|c|c|c|c|c|}
\hline \multirow[t]{3}{*}{ No } & \multirow[t]{3}{*}{ Aspek yang dinilai } & \multicolumn{6}{|c|}{ Nilai } \\
\hline & & \multicolumn{2}{|c|}{ ST } & \multicolumn{2}{|c|}{$\mathbf{T}$} & \multicolumn{2}{|c|}{$\mathrm{R}$} \\
\hline & & $\mathbf{F}$ & $\%$ & $\mathbf{F}$ & $\%$ & $\mathbf{F}$ & $\%$ \\
\hline 1 & $\begin{array}{l}\text { Anak dapat menggambar sesuai idenya } \\
\text { melalui media cetak }\end{array}$ & 11 & 68,75 & 2 & 12,5 & 3 & 18,75 \\
\hline 2 & $\begin{array}{l}\text { Anak dapat membentuk benda (kertas) } \\
\text { sesuai imajinasinya melalui media cetak }\end{array}$ & 10 & 62,5 & 3 & 18,75 & 3 & 18,75 \\
\hline 3 & $\begin{array}{l}\text { Anak dapat mencampur warna sesuai } \\
\text { kreativitasnya }\end{array}$ & 8 & 50 & 2 & 12,5 & 6 & 37,5 \\
\hline \multicolumn{2}{|c|}{ Nilai Rata-rata } & & 60,42 & & 14,58 & & 25 \\
\hline
\end{tabular}

Berdasarkan tabel dan grafik di atas pada siklus I setalah tindakan dideskripsikan bahwa pada aspek ke-1 anak dapat menggambar sesuai idenya melalui media cetak, yang sangat tinggi berjumlah 11 orang dengan persentase $68,75 \%$, anak yang tinggi berjumlah 2 orang dengan persentase $12,5 \%$, dan anak yang rendah berjumlah 3 orang dengan persentase $18,75 \%$. Untuk aspek ke-2 Anak dapat membentuk benda (kertas) sesuai imajinasinya melalui media cetak, yang sangat tinggi berjumlah 10 orang dengan persentase 62,5\%, anak yang tinggi berjumlah 3 orang dengan persentase 18,75\%, dan anak yang rendah berjumlah 3 orang dengan persentase $18,75 \%$. Untuk aspek ke-3 anak dapat mencampur warna sesuai kreativitasnya, yang sangat tinggi berjumlah 8 orang dengan persentase $50 \%$, anak yang tinggi berjumlah 2 orang dengan persentase $12,5 \%$, dan anak yang rendah berjumlah 6 orang dengan persentase $37,5 \%$.

Berdasarkan dari uraian di atas dapat disimpulkan bahwa pada siklus I terjadi peningkatan kreativitas anak melalui media cetak buah-buahan pada setiap pertemuan tetapi belum mencapai kriteria ketuntasan minimum (KKM). Dari tabel di atas dapat dilihat peningkatan kreativitas anak pada siklus I yang terdiri dari 3 kali pertemuan seperti pada grafik di bawah ini.

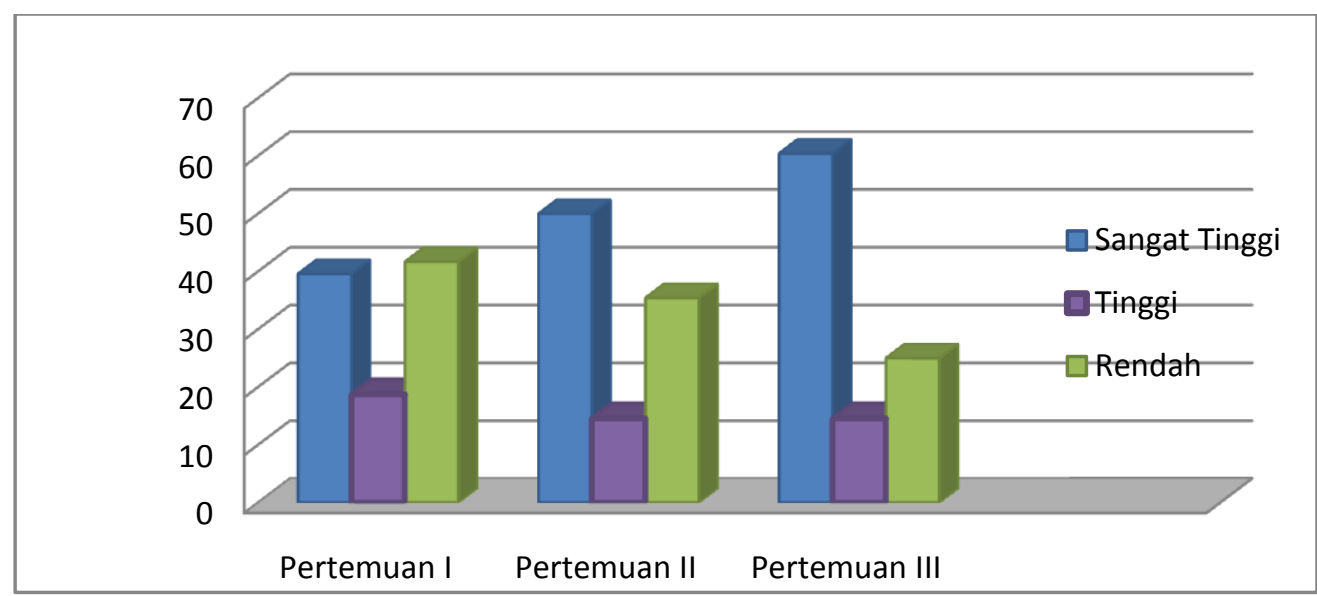

Grafik 1. Rekapitulasi Peningkatan Kreativitas Anak pada Siklus I Pertemuan 1, 2, dan 3 (Setelah Tindakan)

Berdasarkan grafik hasil rekapitulasi observasi di atas peningkatan kreativitas anak melalui media cetak buah-buahan pada siklus I anak nilai rata-rata yang sangat tinggi pada pertemuan pertama 39,58\%, pertemuan kedua $50 \%$, dan pertemuan ketiga $60,42 \%$. Selanjutnya nilai rata-rata anak yang tinggi pada pertemuan pertama $18,75 \%$, pada pertemuan kedua $14,58 \%$, dan pada pertemuan ketiga $14,58 \%$. Nilai ratarata anak yang rendah pada pertemuan I 41,67\%, pertemuan kedua 35,42\%, dan pada pertemuan ketiga menjadi $25 \%$.

\section{Refleksi}

Pelaksanaan pembelajaran pada siklus I sudah sesuai dengan rencana, berdasarkan hasil pengamatan dampak pembelajaran belum cukup berhasil, hal ini dapat terlihat jelas dari:

1. Peningkatan kreativitas anak melalui media cetak buah-buahan meningkat yaitu: 
a. Anak dapat menggambar sesuai idenya melalui media cetak, Peningkatan kreativitas anak yang sangat tinggi dari $18,75 \%$ pada kondisi awal meningkat menjadi $68,75 \%$ pada siklus I pertemuan ketiga.

b. Anak dapat membentuk benda (kertas) sesuai imajinasinya melalui media cetak, Peningkatan kreativitas anak yang sangat tinggi dari $12,5 \%$ pada kondisi awal dan meningkat menjadi $62,5 \%$ pada siklus I pertemuan ketiga.

c. Anak dapat mencampur warna sesuai kreativitasnya, Peningkatan kreativitas anak yang sangat tinggi dari $12,5 \%$ pada kondisi awal dan meningkat menjadi $50 \%$ pada siklus I pertemuan ketiga.

2. Ditinjau dari aktivitas anak, pembelajaran pada siklus I belum berjalan dengan baik. Namun ada beberapa hal yang harus menjadi perhatian guru yaitu:

a. Semua aspek yang dinilai pada siklus I belum tercapai secara maksimal.

b. Penggunaan media belum sepenuhnya dimanfaatkan oleh anak.

Berdasarkan hasil siklus I masih terlihat anak belum mampu melaksanakan kreativitas dengan sangat tinggi, untuk itu peneliti melakukan perbaikan pada siklus II.

\section{Deskripsi Siklus II}

Dari hasil pelaksanaan pada siklus I, ternyata masih belum mencapai Kriteria Ketuntasan Minimal (KKM) maka peneliti melanjutkan penelitian tindakan pada siklus II yang dilaksanakan sebanyak 3 kali pertemuan yaitu pertemuan pertama dilaksanakan pada hari Kamis, tanggal 22 Maret 2018, pertemuan kedua pada hari Sabtu, tanggal 24 Maret 2018, dan pertemuan ketiga pada hari Kamis, 29 Maret 2018.

\section{Pertemuan Pertama}

Hasil dari observasi setiap aspek yang dinilai peningkatan kreativitas anak melalui media cetak buahbuahan secara berkelompok pada siklus II pertemuan pertamadapat dilihat pada tabel berikut:

Tabel 5. Hasil Observasi Peningkatan Kreativitas melalui Media Cetak Buah-buahan Pada Siklus II Pertemuan Pertama

\begin{tabular}{|c|c|c|c|c|c|c|c|}
\hline \multirow[t]{3}{*}{ No } & \multirow[t]{3}{*}{ Aspek yang dinilai } & \multicolumn{6}{|c|}{ Nilai } \\
\hline & & \multicolumn{2}{|c|}{ ST } & \multicolumn{2}{|c|}{$\mathbf{T}$} & \multicolumn{2}{|c|}{$\mathrm{R}$} \\
\hline & & $\mathbf{F}$ & $\%$ & $\mathbf{F}$ & $\%$ & $\mathbf{F}$ & $\%$ \\
\hline 1 & $\begin{array}{l}\text { Anak dapat menggambar sesuai } \\
\text { idenya melalui media cetak }\end{array}$ & 12 & 75 & 1 & 6,25 & 3 & 18,75 \\
\hline 2 & $\begin{array}{l}\text { Anak dapat membentuk benda } \\
\text { (kertas) sesuai imajinasinya } \\
\text { melalui media cetak }\end{array}$ & 11 & 68,75 & 2 & 12,5 & 3 & 18,75 \\
\hline 3 & $\begin{array}{l}\text { Anak dapat mencampur warna } \\
\text { sesuai kreativitasnya }\end{array}$ & 9 & 56,25 & 2 & 12,5 & 5 & 31,25 \\
\hline Nilai & a-rata & & 66,67 & & 10,42 & & 22,92 \\
\hline
\end{tabular}

Berdasarkan temuan penelitian siklus II diperoleh persentase sebagai berikut: pada aspek ke-1 anak dapat menggambar sesuai idenya melalui media cetak, yang sangat tinggi berjumlah 12 orang dengan persentase $75 \%$, anak yang tinggi berjumlah 1 orang dengan persentase $6,25 \%$, dan anak yang rendah berjumlah 3 orang dengan persentase 18,75\%. Untuk aspek ke-2 Anak dapat membentuk benda (kertas) sesuai imajinasinya melalui media cetak, yang sangat tinggi berjumlah 11 orang dengan persentase $68,75 \%$, anak yang tinggi berjumlah 2 orang dengan persentase 12,5\%, dan anak yang rendah berjumlah 3 orang dengan persentase $18,75 \%$. Untuk aspek ke-3 anak dapat mencampur warna sesuai kreativitasnya, yang sangat tinggi berjumlah 9 orang dengan persentase 56,25\%, anak yang tinggi berjumlah 2 orang dengan persentase $12,5 \%$, dan anak yang rendah berjumlah 5 orang dengan persentase $31,25 \%$.

Berdasarkan persentase kegiatan pertemuan pertama siklus II diperoleh persentase anak kategori sangat tinggi sebesar $66,67 \%$, kategori tinggi 10,42\%, dan kategori rendah 22,92\%.

\section{Pertemuan Kedua}

Hasil dari observasi setiap aspek yang dinilai peningkatan kreativitas anak melalui media cetak buahbuahan pada siklus II pertemuan keduadapat dilihat pada tabel berikut: 
Tabel 6. Hasil Observasi Peningkatan Kreativitas Anak melalui Media Cetak Buah-buahan Pada Siklus II Pertemuan kedua

\begin{tabular}{|c|c|c|c|c|c|c|c|}
\hline \multirow[t]{3}{*}{ No } & \multirow[t]{3}{*}{ Aspek yang dinilai } & \multicolumn{6}{|c|}{ Nilai } \\
\hline & & \multicolumn{2}{|c|}{ ST } & \multicolumn{2}{|c|}{$T$} & \multicolumn{2}{|c|}{$\overline{\mathrm{R}}$} \\
\hline & & $\mathbf{F}$ & $\%$ & $\mathbf{F}$ & $\%$ & $\mathbf{F}$ & $\%$ \\
\hline 1 & $\begin{array}{l}\text { Anak dapat menggambar sesuai } \\
\text { idenya melalui media cetak }\end{array}$ & 13 & 81,25 & 1 & 6,25 & 2 & 12,5 \\
\hline 2 & $\begin{array}{l}\text { Anak dapat membentuk benda } \\
\text { (kertas) sesuai imajinasinya melalui } \\
\text { media cetak }\end{array}$ & 13 & 81,25 & 2 & 12,5 & 1 & 6,25 \\
\hline 3 & $\begin{array}{l}\text { Anak dapat mencampur warna } \\
\text { sesuai kreativitasnya }\end{array}$ & 10 & 62,5 & 2 & 12,5 & 4 & 25 \\
\hline Nil & i Rata-rata & & 75 & & 10,42 & & 14,58 \\
\hline
\end{tabular}

Berdasarkan temuan penelitian siklus kedua diperoleh persentase sebagai berikut: pada aspek ke-1 anak dapat menggambar sesuai idenya melalui media cetak, yang sangat tinggi berjumlah 13 orang dengan persentase $81,25 \%$, anak yang tinggi berjumlah 1 orang dengan persentase $6,25 \%$, dan anak yang rendah berjumlah 2 orang dengan persentase 12,5\%. Untuk aspek ke-2 Anak dapat membentuk benda (kertas) sesuai imajinasinya melalui media cetak, yang sangat tinggi berjumlah 13 orang dengan persentase $81,25 \%$, anak yang tinggi berjumlah 2 orang dengan persentase 12,5\%, dan anak yang rendah berjumlah 1 orang dengan persentase $6,25 \%$. Untuk aspek ke-3 anak dapat mencampur warna sesuai kreativitasnya, yang sangat tinggi berjumlah 10 orang dengan persentase $62,5 \%$, anak yang tinggi berjumlah 2 orang dengan persentase $12,5 \%$, dan anak yang rendah berjumlah 4 orang dengan persentase $25 \%$.

\section{Pertemuan Ketiga}

Hasil dari observasi setiap aspek yang dinilai peningkatan kreativitas anak melalui media cetak buahbuahanpada siklus II pertemuan ketigadapat dilihat pada tabel berikut:

Tabel 7. Hasil Observasi Peningkatan Kreativitas Anak melalui Media Cetak Buah-buahan (Setelah Tindakan) Pada Siklus II Pertemuan Ketiga

\begin{tabular}{|c|c|c|c|c|c|c|c|}
\hline \multirow[t]{3}{*}{ No } & \multirow[t]{3}{*}{ Aspek yang dinilai } & \multicolumn{6}{|c|}{ Nilai } \\
\hline & & \multicolumn{2}{|c|}{ ST } & \multicolumn{2}{|c|}{$\mathbf{T}$} & \multicolumn{2}{|c|}{$\mathrm{R}$} \\
\hline & & $\mathbf{F}$ & $\%$ & $\mathbf{F}$ & $\%$ & $\mathbf{F}$ & $\%$ \\
\hline 1 & $\begin{array}{l}\text { Anak dapat menggambar sesuai } \\
\text { idenya melalui media cetak }\end{array}$ & 14 & 87,5 & 1 & 6,25 & 1 & 6,25 \\
\hline 2 & $\begin{array}{l}\text { Anak dapat membentuk benda } \\
\text { (kertas) sesuai imajinasinya } \\
\text { melalui media cetak }\end{array}$ & 15 & 93,75 & 1 & 6,25 & - & $\mathbf{0}$ \\
\hline 3 & $\begin{array}{l}\text { Anak dapat mencampur warna } \\
\text { sesuai kreativitasnya }\end{array}$ & 12 & 75 & 2 & 12,5 & 2 & 12,5 \\
\hline \multicolumn{2}{|c|}{ Nilai Rata-rata } & & 85,42 & & 8,33 & & 6,25 \\
\hline
\end{tabular}

Berdasarkan tabel dan grafik di atas pada siklus II setelah tindakan dideskripsikan bahwa pada aspek ke-1 anak dapat menggambar sesuai idenya melalui media cetak, yang sangat tinggi berjumlah 14 orang dengan persentase $87,5 \%$, anak yang tinggi berjumlah 1 orang dengan persentase $6,25 \%$, dan anak yang rendah berjumlah 1 orang dengan persentase 6,25\%. Untuk aspek ke-2 Anak dapat membentuk benda (kertas) sesuai imajinasinya melalui media cetak, yang sangat tinggi berjumlah 15 orang dengan persentase $93,75 \%$, anak yang tinggi berjumlah 1 orang dengan persentase $6,25 \%$, dan anak yang rendah berjumlah 0 orang dengan persentase $0 \%$. Untuk aspek ke-3 anak dapat mencampur warna sesuai kreativitasnya, yang sangat tinggi berjumlah 12 orang dengan persentase $75 \%$, anak yang tinggi berjumlah 2 orang dengan persentase $12,5 \%$, dan anak yang rendah berjumlah 2 orang dengan persentase $12,5 \%$.

Berdasarkan dari uraian di atas dapat disimpulkan bahwa pada siklus II terjadi peningkatan kreativitas anak melalui media cetak buah-buahan pada setiap pertemuan telah tuntas dan mencapai kriteria ketuntasan minimum (KKM). Dari tabel di atas dapat dilihat peningkatan Peningkatan kreativitas anak pada siklus II yang terdiri dari 3 kali pertemuan seperti pada grafik di bawah ini. 


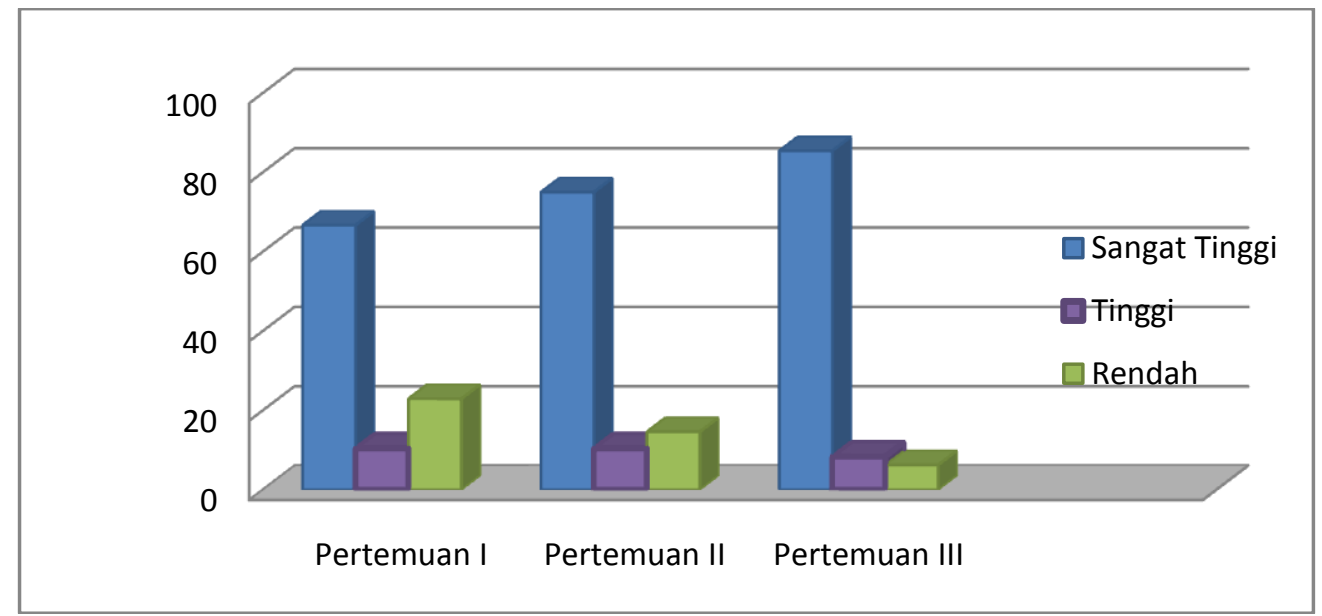

Grafik 1. Rekapitulasi Peningkatan Kreativitas Anak pada Siklus II, Pertemuan 1, 2, dan 3 (setelah tindakan)

Berdasarkan grafik hasil rekapitulasi di atas peningkatan kreativitas anak melalui media cetak buahbuahan pada siklus II anak nilai rata-rata yang sangat tinggi pada pertemuan pertama 66,67\%, pertemuan kedua $75 \%$, dan pertemuan ketiga $85,42 \%$. Selanjutnya nilai rata-rata anak yang tinggi pada pertemuan pertama $10,42 \%$, pada pertemuan kedua $10,42 \%$, dan pada pertemuan ketiga $8,33 \%$. Nilai rata-rata anak yang rendah pada pertemuan pertama $22,92 \%$, pertemuan kedua $14,58 \%$, dan pada pertemuan ketiga menjadi $6,25 \%$.

\section{Refleksi}

Keberhasilan yang telah diperoleh selama siklus II adalah sebagai berikut:

1) Peningkatan kreativitas anak dalam pembelajaran meningkat dan pada umumnya berada dalam kategori baik dibandingkan pada siklus I.

2) Pada siklus II ini sikap percaya diri dan keberanian anak melalui media cetak buah-buahan meningkat dibandingkan dengan siklus I.

Berdasarkan hasil penelitian tersebut dan dari hasil pencapaian pada akhir siklus I dan siklus II peneliti berkeyakinan bahwa melalui media cetak buah-buahan dapat meningkatkan peningkatan kreativitas anak kelas B1TK Pertiwi Pasar Baru Bayang Kabupaten Pesisir Selatan .Di akhir siklus II pertemuan Ketiga KKM sudah tercapai 75\%, maka penelitian dicukupkan sampai disini.

\section{PEMBAHASAN}

Sesuai dengan hasil penelitian peningkatan kreativitas anak di TK Pertiwi Pasar Baru Bayang Kabupaten Pesisir Selatan, perlu pembahasan untuk menjelaskan dan memperdalam kajian pada penelitian ini. Kemampuan anak dalam berkreativitas masih rendah tergambar pada kondisi awal. Sebagian anak dikelmpok B1 di TK Pertiwi Pasar Baru Bayang Kabupaten Pesisir Selatan masih belum bisa mengungkapkan idenya. Setelah melihat kondisi awal tentang kreativitas anak di TK Pertiwi Pasar Baru Bayang Kabupaten Pesisir Selatan , peneliti melakukan tindakan untuk memperbaiki metode pembelajaran melalui media cetak buah-buahan.

Ditinjau dari aspek anak dapat menggambar sesuai idenya melalui media cetakterlihat nilai rata-rata sebelum tindakanrendah, siklus I tinggi, dan meningkat pada siklus II sangat tinggiKarena di akhir siklus I hasilnya belum optimal maka dilanjutkan pada siklus II dilaksanakan dengan memperbanyak media.Hal ini sesuai dengan pendapat Arsyad (1967) mengatakan dengan penggunaan media yang tepat dapat mempelancar pembelajaran dan mendapatkan hasil yang maksimal dan memberikan motivasi dan arahan serta membimbing dalam pembelajaran sehingga hasil yang dicapai optimal. Hal ini sesuai dengan pendapat Sadiman (1986) dengan motivasi dapat mengoptimalkan hasil belajar anak dengan demikian hasil pembelajaran anak dapat meningkat baik.

Aspek anak dapat membentuk benda (kertas) sesuai imajinasinya melalui media cetakterlihat nilai rata-rata sebelum tindakan rendah, siklus I tinggi, dan meningkat pada siklus II sangat tinggi. Hal ini didukung oleh 
pendapat Setiawan (2002), yang mengacu pada teori Piaget, anak usia dini dapat di katakan sebagai usia yang belum dapat di tuntut untuk berpikir secara logis, yang di tandai dengan pemikiran. Jadi melalui media cetak buah-buahan dapat meningkatkan kreativitas anak dapat membentuk benda (kertas) sesuai imajinasinya.

Aspek anak dapat mencampur warna sesuai kreativitasnyaterlihat nilai rata-rata sebelum tindakan rendah, siklus I masih rendah, dan meningkat pada siklus II meningkat menjadi sangat tinggi.Hal ini didukung oleh pendapat Munandar (1995) yaitu kreativitas sebagai media untuk membuat kombinasi-kombinasi baru, asosiasi baru berdasarkan bahan, informasi, data atau elemen-elemen yang sudah ada sebelumnya menjadi hal-hal yang bermakna dan bermanfaat.Jadi melalui media cetak buah-buahan dapat meningkatkan kreasi anak dapat mencampur warna sesuai kreativitasnya.

Berdasarkan ketiga aspek yang telah diteliti dan melihat persentase dari masing-masing aspek terjadinya peningkatan yang signifikan. Maka dapat diambil kesimpulan bahwa melalui media cetak buah-buahan dapat meningkatakn kreativitas anak di TK Pertiwi Pasar Baru Bayang Kabupaten Pesisir Selatan .

\section{KESIMPULAN}

Berdasarkan hasil penelitian dan pembahasan yang telah diuraikan, maka dapat diambil kesimpulan sebagai berikut: 1) Taman kanak-kanak merupakan langkah awal untuk mengenalkan pada anak tentang dunia sekolah, menciptakan lingkungan yang menyenangkan bukan menuntut mereka untuk dapat menguasai peningkatan kreativitas secara lancar dan menyeluruh. Namun pada kenyataan berdasarkan pengamatan di lapangan, anak dibiarkan saja tanpa didampingi dan diiringi dengan pengetahuan dan wawasan yang lebih; 2) Pada hakikatnya pendidikan anak usia dini adalah pemberian upaya untuk menstimulasi, membimbing, mengasuh, dan menyediakan sarana dan kegiatan pembelajaran yang dilakukan tersebut dengan cara bermain sambil belajar dan belajar seraya bermain. Untuk itu pendidikan anak usia dini adalah upaya untuk menfasilitasi pertumbuhan dan perkembangan anak; 3) Pelaksanaan media cetak buah-buahan dapat meningkatkan kreativitas anak terhadap perkembangan anak untuk mengelola dan mengontrol koordinasi kreativitas, mengenalkan dan melatih kreativitas; 4) Agar tujuan peningkatan kreativitas anak dapat tercapai secara optimal diperlukan strategi dan pendekatan yang sesuai dengan karakteristik pembelajaran di TK yaitu melalui bermain dengan menggunakan metode mengajar yang tepat untuk peningkatan kreativitas serta melibatkan anak secara langsung dalam kegiatan yang dapat memberikan berbagai pengalaman bagi anak; 5) Membelajarkan anak dengan upaya peningkatan kreativitas melalui media cetak buah-buahan akan dapat menumbuhkan minat, percaya diri, keberanian, dan rasa keingintahuan anak; 6) Ketika anak sedang bergerak, sesungguhnya ia tidak hanya menambah ketajaman berpikirnya, pada saat yang sama perasaan anak terasah sehingga secara keseluruhan ia mengembangkan perkembangan kreativitas seni dan intelektualnya sekaligus meningkatkan kecakapan mentalnya.

\section{DAFTAR RUJUKAN}

Arikunto. (2008). Prosedur Penelitian. Jakarta: PT Rineka Cipta.

Arsyad, Azhar. (2006). Media Pembelajaran. Jakarta: PT. Raja Grafindo Persada.

Evawita. (2011). "Peningkatan Kreativitas Bahasa Anak melalui Permainan Order Boxes di TK Seroja padang".(Skripsi). Padang: FIP UNP.

Hurlock. (1997). Psikologi Perkembangan Anak. Jakarta: Erlangga.

Mulyadi, Seto. (2004). Meningkatkan Kreativitas dalam Belajar. Jakarta: Papas Sinar Sinanti.

Rachmawati, Yeni. (2010). Strategi Pengembangan Kreativitas pada Anak. Jakarta: Kencana Prenada Media Group.

Sanjaya, Wina. (2010). Penelitian Tindakan Kelas. Jakarta: Prenada Media Group.

Semiawan, C. (2002). Paradigma Baru PAUD dalam Rangka Sosialisasi PAUD. Jakarta: Depdiknas.

Suratno. (2005). Pengembangan Kreativitas Anak Usia Dini. Jakarta: Depdiknas.

Suyanto, Slamet. (2005). Konsep Dasar Anak Usia Dini. Jakarta: Depdiknas Dirjen Dikti.

Undang - Undang Republik Indonesia. (2003). Sistem Pendidikan Nasional No 20. Jakarta: Depdiknas. 